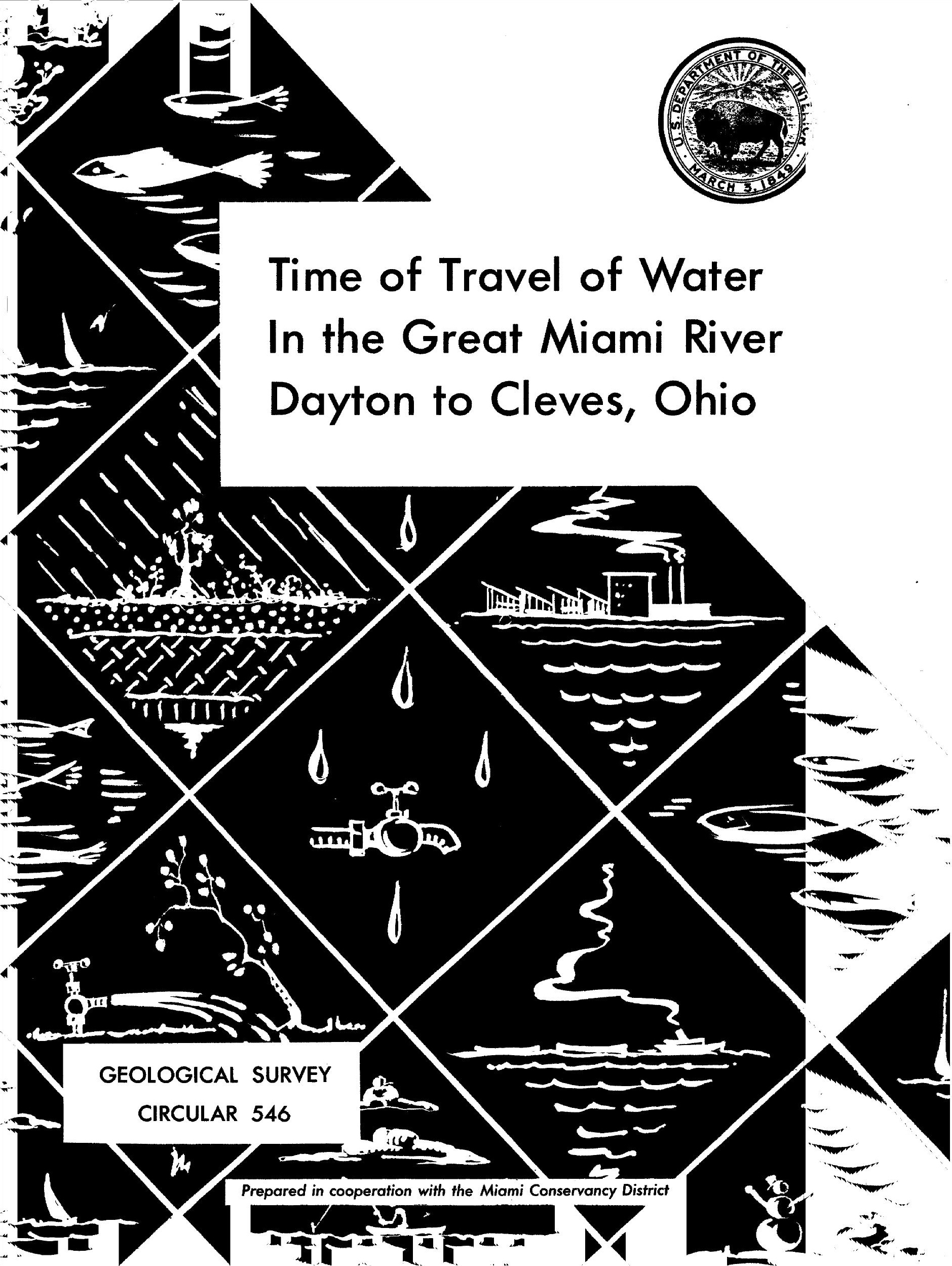





\title{
Time of Travel of Water In the Great Miami River Dayton to Cleves, Ohio
}

\author{
By Daniel P. Bauer
}

GEOLOGICAL SURVEY CIRCULAR 546

Prepared in cooperation with the Miami Conservancy District

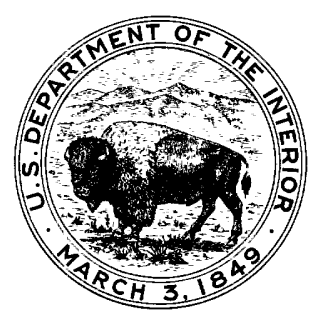


United States Department of the Interior STEWART L. UDALL, Secretary

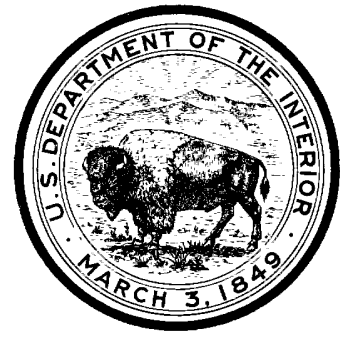

Geological Survey

William T. Pecora, Director<smiles>[V]</smiles> 


\section{CONTENTS}

Page

Page

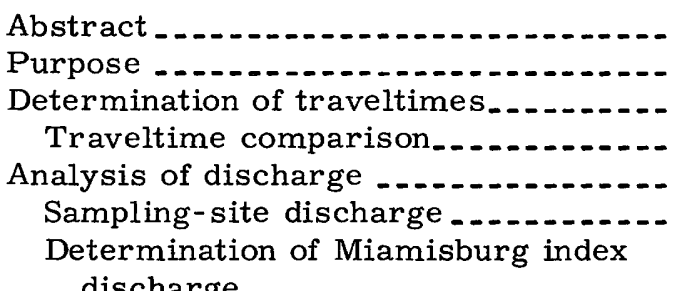

Traveltime prediction .

Dye-cloud passage time............ 15

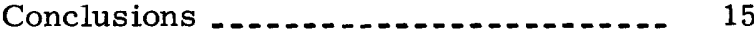

Selected references _............... 15

ILLUSTRATIONS

Pege

Figure 1. Time distribution of dye concentration, Central Avenue, Middletown

2. Map of Great Miami River basin

2

3

3-8. Graph showing traveltime of-

3. Great Miami River, mile 80 to mile 40

4

4. Great Miami River, mile 40 to mile 0

5. Dye cloud and longitudinal dispersion characteristics of Great Miami

River at index flow of 550 cubic feet per second, mile 80 to mile $35 \ldots . .$.

6. Dye cloud and longitudinal dispersion characteristics of Great Miami

River at index flow of 550 cubic feet per second, mile 40 to mile $0 . . . .$.

7. Dye cloud and longitudinal dispersion characteristics of Great Miami

River at index flow of 380 cubic feet per second, mile 80 to mile $35 \ldots . .$.

8. Dye cloud and longitudinal dispersion characteristics of Great Miami

River at index flow of 380 cubic feet per second, mile 40 to mile $0 . . . .$.

Table 1. Traveltime for index discharge of 550 cubic feet per second at Miamisburg....-

Page

TABLES

2. Traveltime for index discharge of 380 cubic feet per second at Miamisburg....-

3. Discharges at selected sites on Great Miami River and tributaries ......

4. Municipal sewage-plant effluent

5. Waste effluent from industries using ground-water supply

6. Miamisburg index discharges for mean discharges in subreaches during August run 



\title{
Time of Travel of Water in the Great Miami River, Dayton to Cleves, Ohio
}

\author{
By Daniel P. Bauer
}

ABSTRACT

A time-of-travel study of the Great Miami River from Dayton to Cleves, Ohio, a distance of 71.3 river miles, was made in the summer of 1965 to obtain basic information about water passage. Cumulative traveltimes of 182 and 254 hours were determined for approximate discharges of 550 and $380 \mathrm{cfs}$ (cubic feet per second), respectively, at Miami sburg.

Peak traveltimes averaged 91 percent of the centroid traveltimes for the entire reach from Dayton to Cleves. Traveltimes computed from the so-called average-velocity method (discharge/cross-sectional area) were somewhat shorter for a given index discharge than the traveltimes determined for the centroid of the dye cloud.

A method utilizing a straight-line log-log plot of traveltime versus index discharge to predict approximate traveltimes is stated. The resulting equation, $T=400 \times 10^{2} Q^{-.85}$, is limited

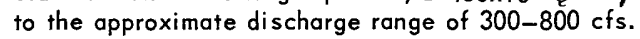

\section{PURPOSE}

The Great Miami River, like many streams used extensively by man to carry away municipal and industrial wastes, receives large quantities of waste water from many sources. During summer low-flow periods the Great Miami River has high water temperatures and low dissolved-oxygen concentrations in some reaches downstream from Dayton, Ohio. During such periods information on time of travel is necessary to predict the passage of pollutants accidentally spilled into the river.

A time-of-travel study of the Great Miami River from Dayton to Cleves, Ohio, 71.3 river miles, was made in the summer of 1965 to obtain basic information about water passage. The study was made with a fourfold purpose:
1. To determine the traveltime between given sites along the stream for use in pollution studies.

2. To examine the longitudinal dispersion of the dye cloud, expressed as passage time at selected sampling sites.

3. To compare the time of travel based on the average velocity computed from discharge divided by cross-sectional area with that of the dye.

4. To examine the possibilities of preticting traveltimes at different discharges.

The techniques utilizing a soluble dye tracer were developed by the U.S. Geological Survey and were perfected by measurements on many streams prior to this study (Buchanan, 1964; Wilson and Forest, 1965).

The study was made under a cooperative program between the Miami Conservancy District, M. L. Mitchell, chief engineer, and the U.S. Geological Survey, Water Resources Division, Columbus, Ohio, J. J. Molloy, district chief, H. P. Brooks, U.S. Geological Survey, and L. C. Crawford, Miami Conservancy District, coordinated the field operations.

\section{DETERMINATION OF TRAVELTIMES}

To determine traveltime, a soluble dye, Rhodamine BA, was used as a tracer. The study reach, 71.3 river miles, was divided into 7 subreaches during the July run and 9 subreaches during the August run to minimize dye concentration and total time required for the 


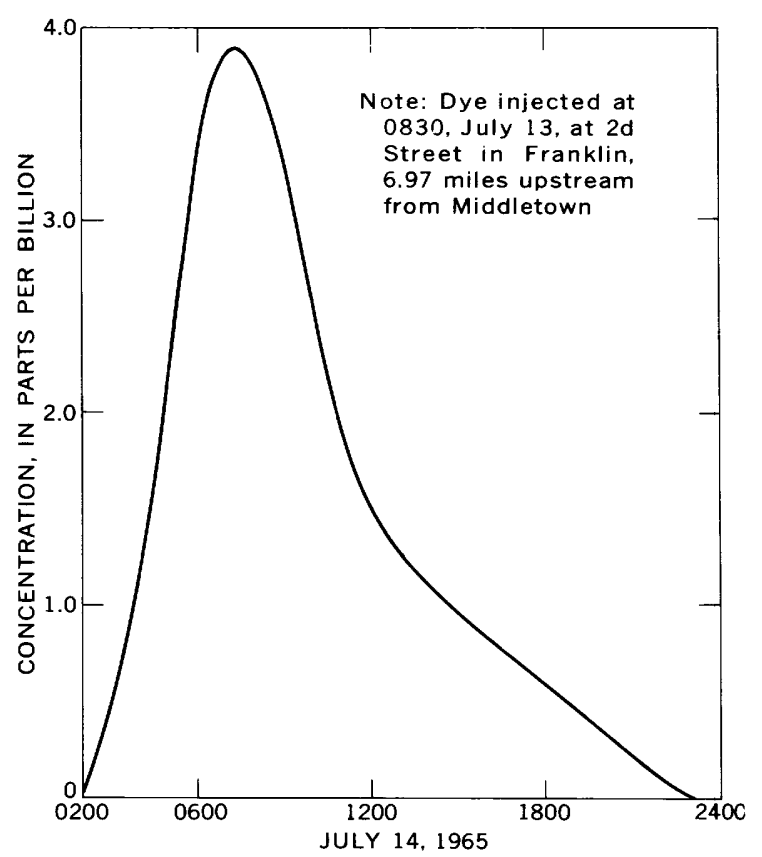

Figure 1. - Time distribution of dye concentration, Central Avenue, Middletown.

study. The dye was injected into the river as a slug at the head of each subreach. Water samples were then collected at selected sites downstrram from the injection site. The samples were tested for dye concentrations with an instrument called a fluorometer. From the tests the time distribution of the tracer was determined for each sampling site and plotted as shown in figure 1. From such graphs the data presented in this report were extracted. This study required a 20-man field crew for each run.

From Dayton to Cleves (fig. 2), cumulative traveltimes of 182 and 254 hours were computed at approximate index discharges of 550 and $380 \mathrm{cfs}$ (cubic feet per second). The Miamisburg gage was selected as the index station for the study reach. These traveltimes, shown in figures 3 and 4 , are for the centroid of the dye-cloud mass.

The approximate peak traveltimes are listed in tables 1 and 2. Many of the concentration curves contained two or more peaks of approximately equal magnitude, particularly during the August run. The peak-time occurrence was then computed by weighting each peak time by its respective concentration magnitude. During the July run multiple peaks did not occur, but some curves had poorly defined peaks, which made determinations of peak traveltime equally difficult.

\section{TRAVELTIME COMPARISON}

A curve computed by using the averagevelocity method for an index discharge of 394 cfs at Miamisburg was available previous to this study. The average velocity was computed by dividing the average discharge in a subreach by the average cross-sectional area. Traveltime was then obtained by dividing the average reach length by the average velocity. A curve using average velocity traveltime is shown in figures 3 and 4 . Data for the curve were obtained from the Miami Conservancy District. It plots between the curves developed from the traveltime of the dye clcids and indicates a traveltime too short for the discharge.

In the entire reach, Dayton to Cleves, for the $J u l y$ and August runs, the peak traveltimes averaged 91 percent of the centroid traveltimes (figs, 5-8). Curve characteristics for the two runs appear to agree fairly closely.

\section{ANALYSIS OF DISCHARGE}

\section{SAMPLING-SITE DISCHARGE}

To compute the discharges for sampling sites shown in tables 1 and 2, a point-source method was used. By this method any contributing tributary discharge and industrial-or municipal-sewage effluent were added to the streamflow. For most sites, a true balance of discharge at the downstream end of the reach was not achieved. To refine the discharge further, a discharge-drainage-ares. computation was applied for each sampling site.

Because of the lack of knowledge of flow diversion at the Hamilton diversion canal, it was assumed that most of the flow would travel through the canal. During the July run a sampling station was located on the river within the canal-river complex. Results of the run indicated that only a small portion of the flow took the river route; most of the flow traveled through the canal. During the f ugust run no samples were taken at this river site.

No canal-discharge measurements were made at Franklin. However, a canal-discharge estimate of $225 \mathrm{cfs}$ was made using dye-cloud mass recovery at Franklin. This estimate was made by dividing the area under the dye-cloud concentration curve for the canal outfall by the area under the curve for Franklin; this quotient was then multiplied by the total discharge at Franklin. The computation assumed 


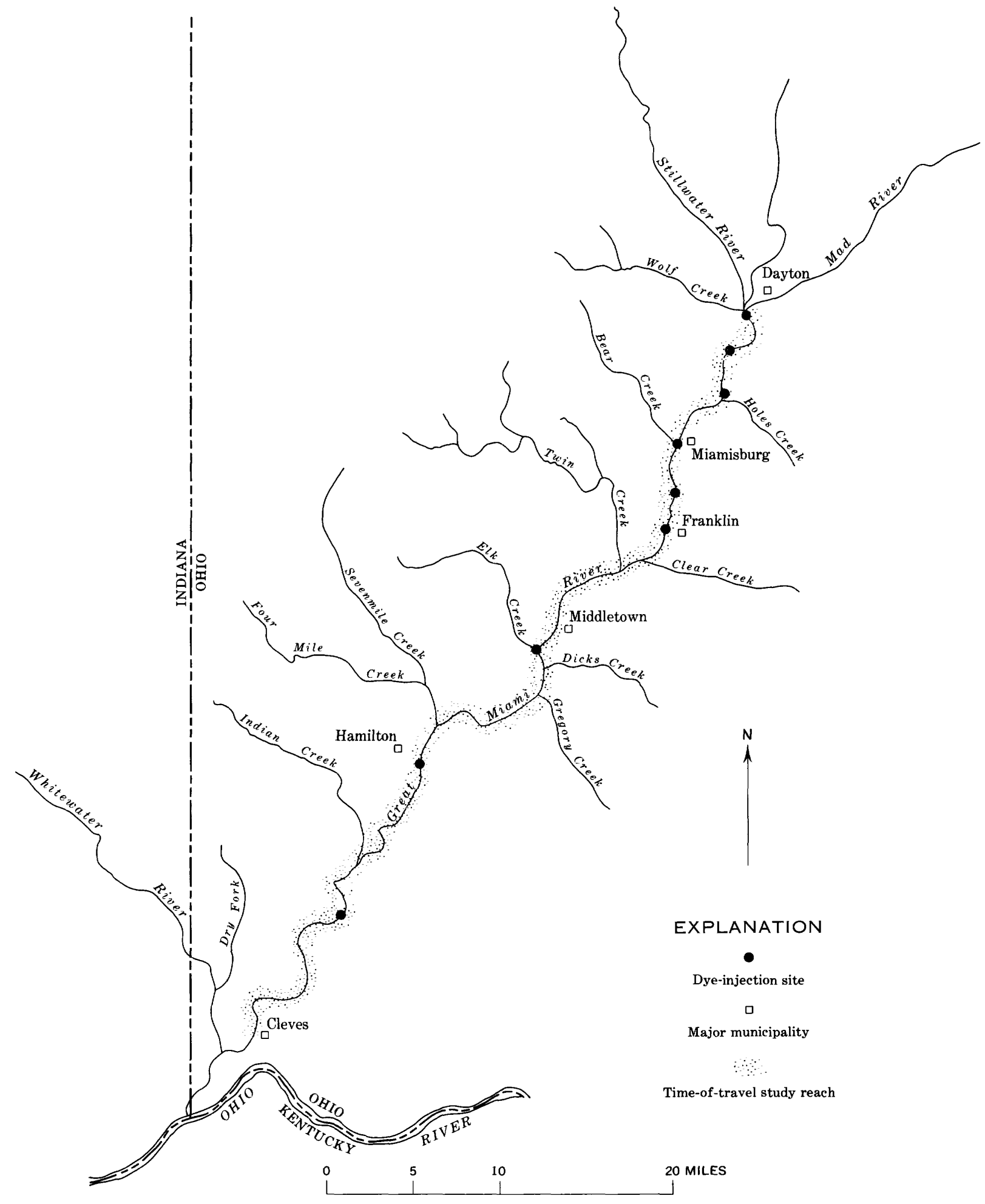

Figure 2. - Great Miami River basin. 


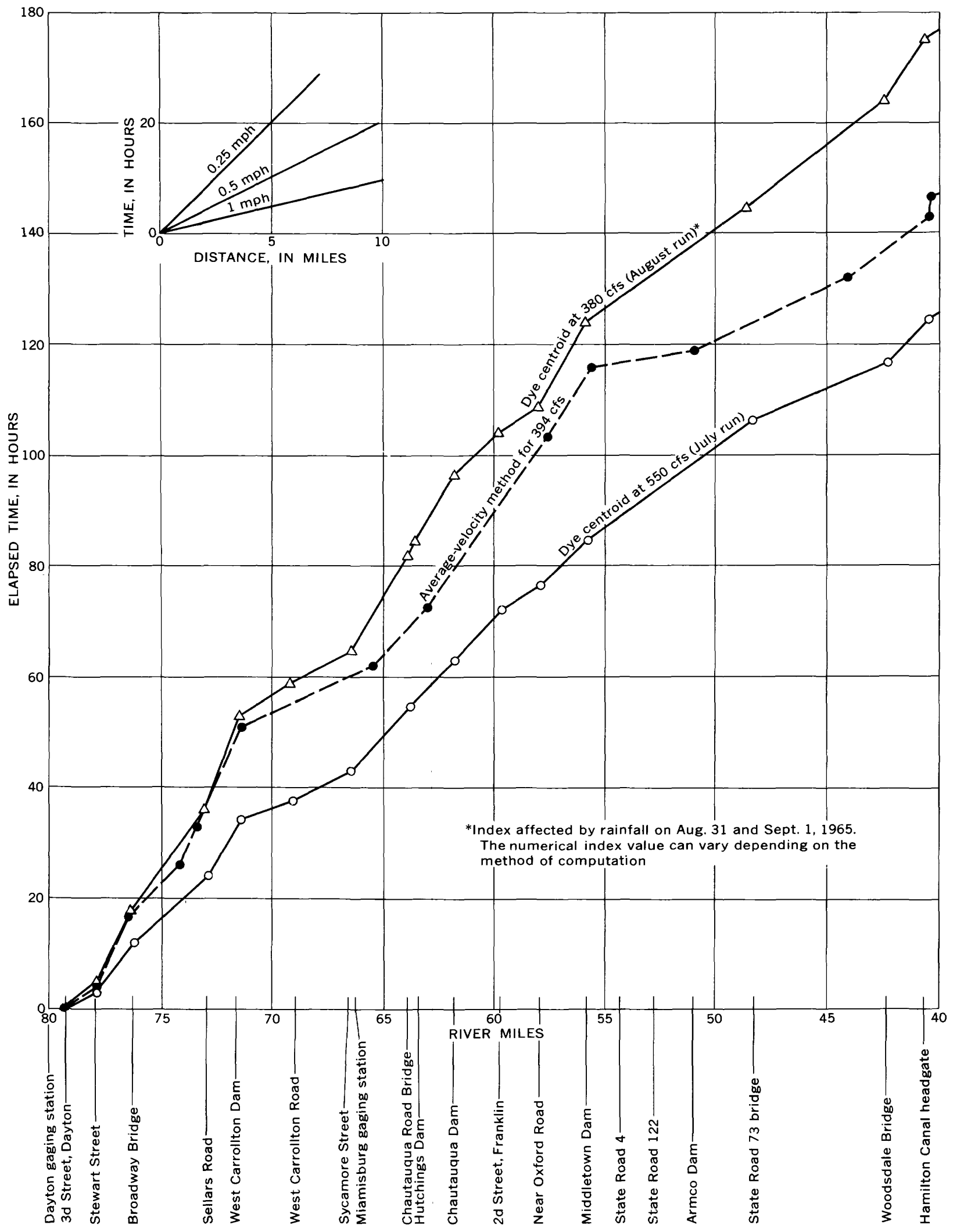

Ftgure 3. - Traveltime of Great Miami River, mile 80 to mile 40. 


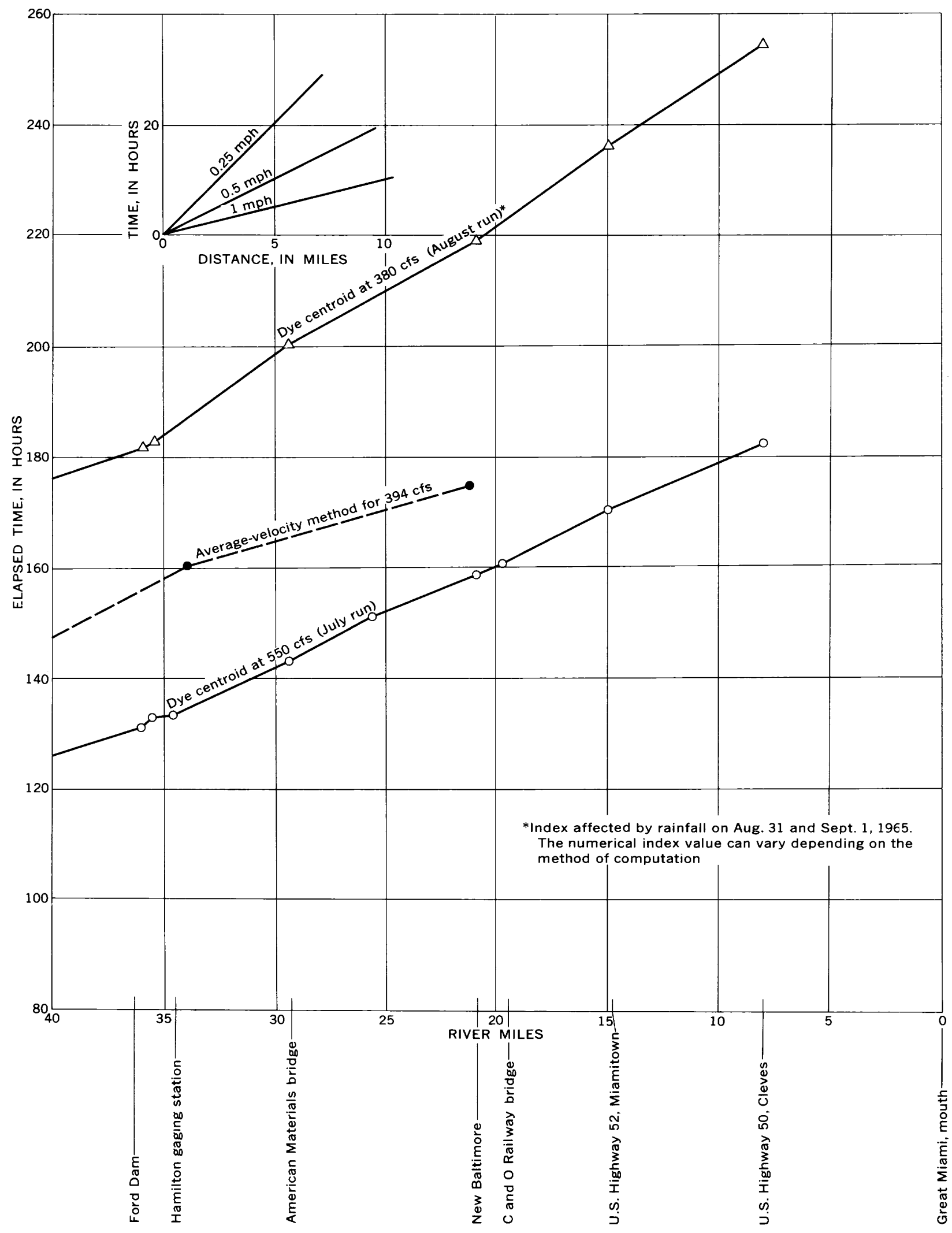

Figure 4. -Traveltime of Great Miami River, mile 40 to mile 0. 


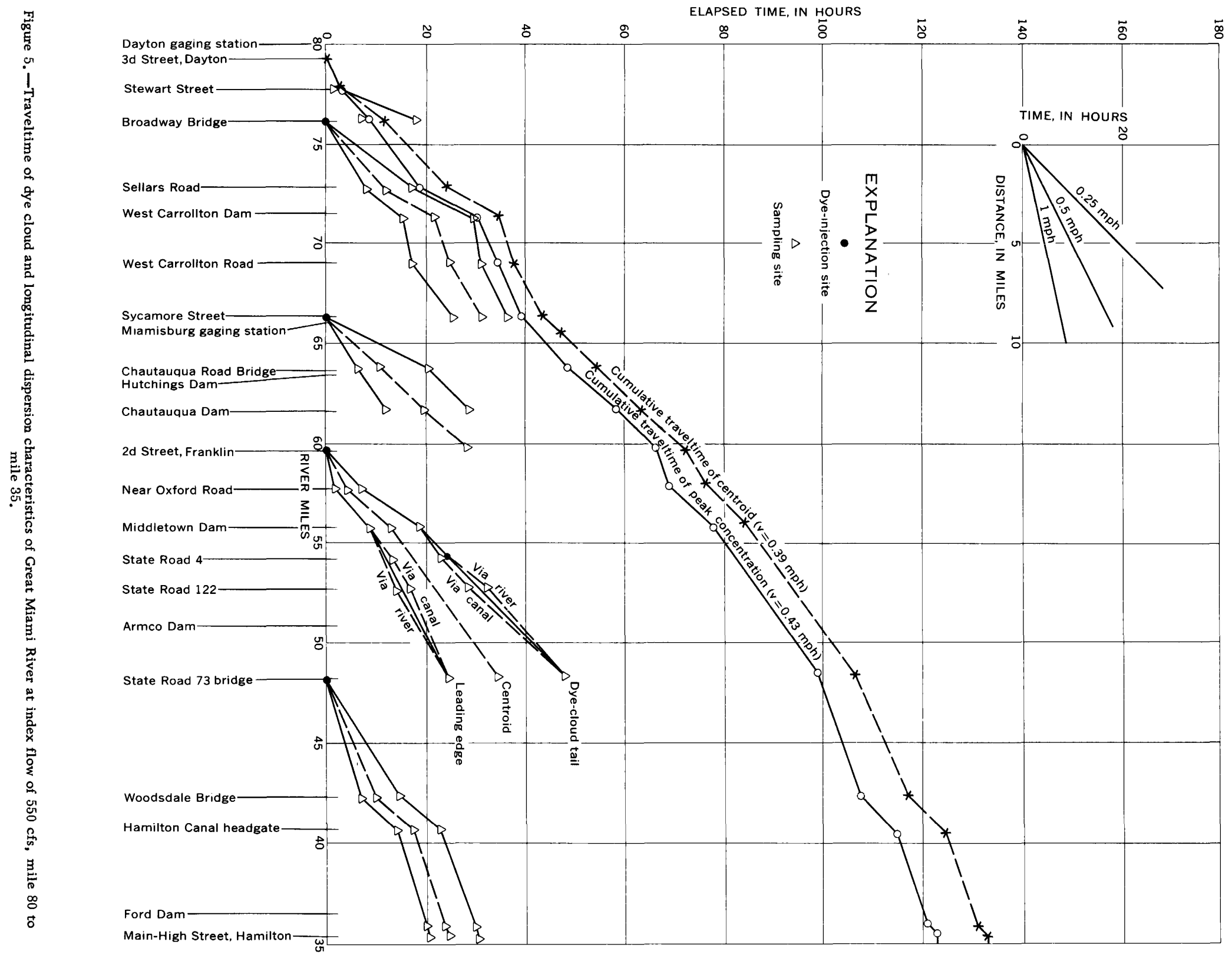




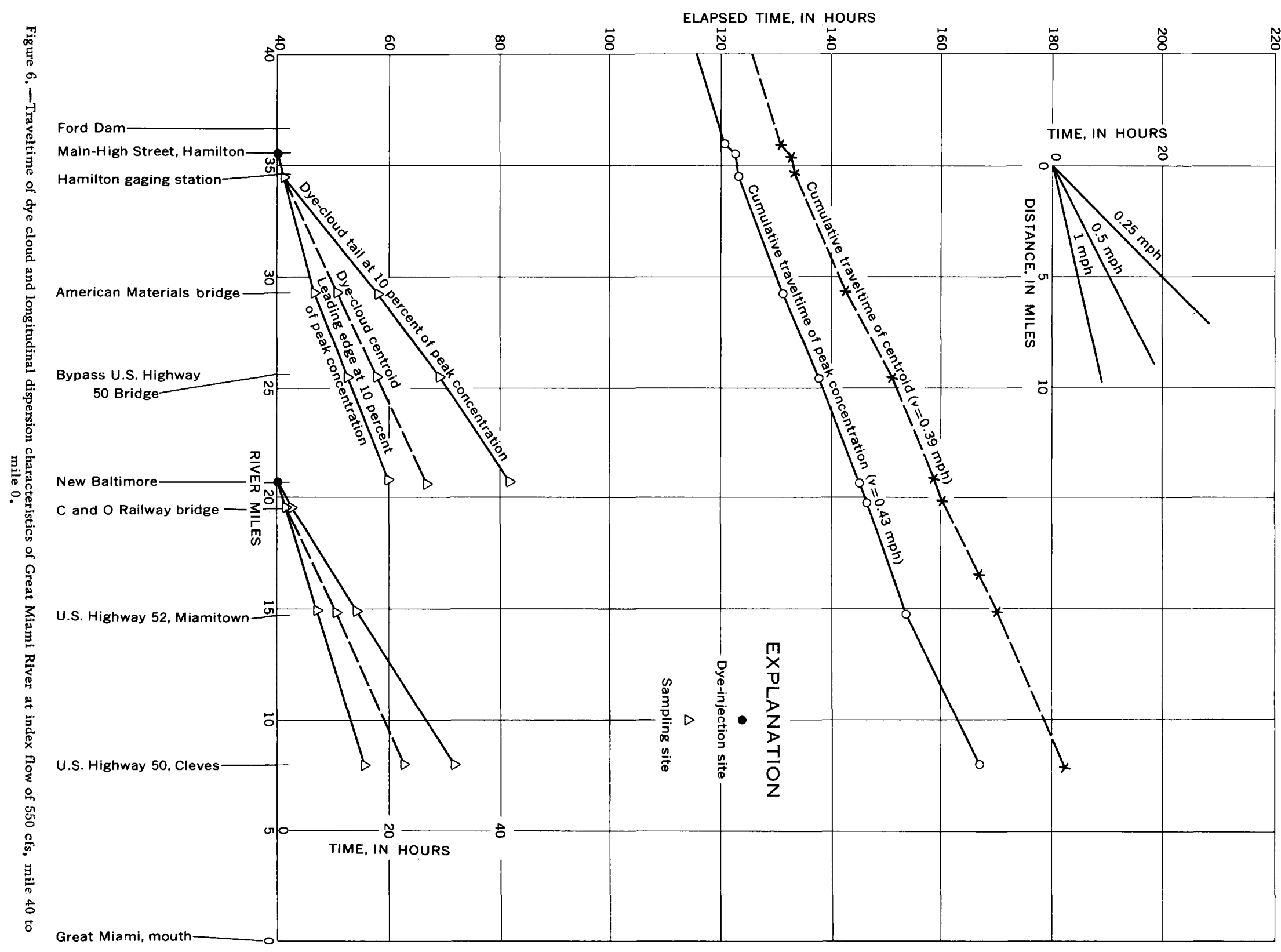




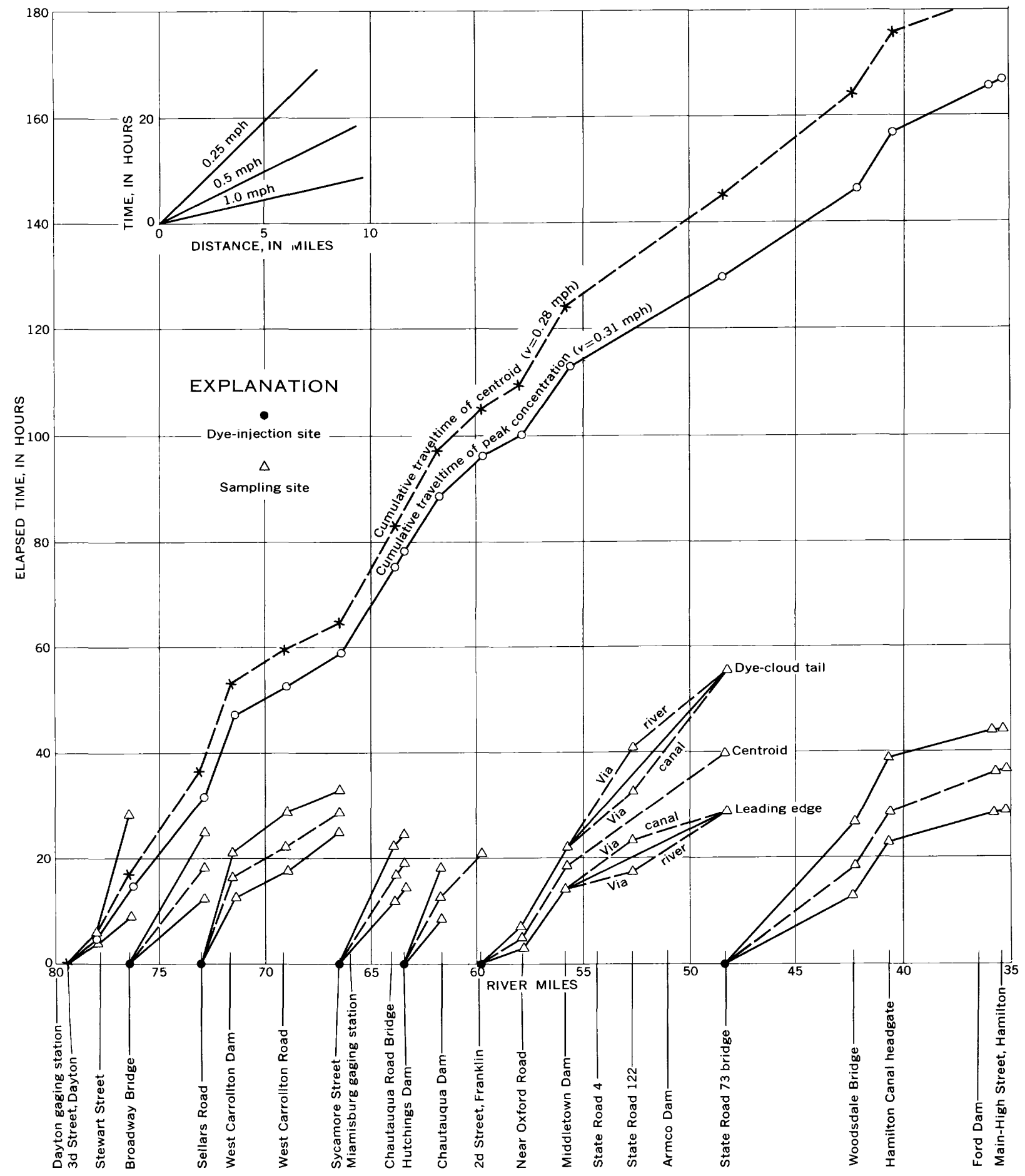

Figure 7. - Traveltime of dye cloud and longitudinal dispersion characteristics of Great Miami River at index flow of 380 cfs, mile 80 to mile 35 . 


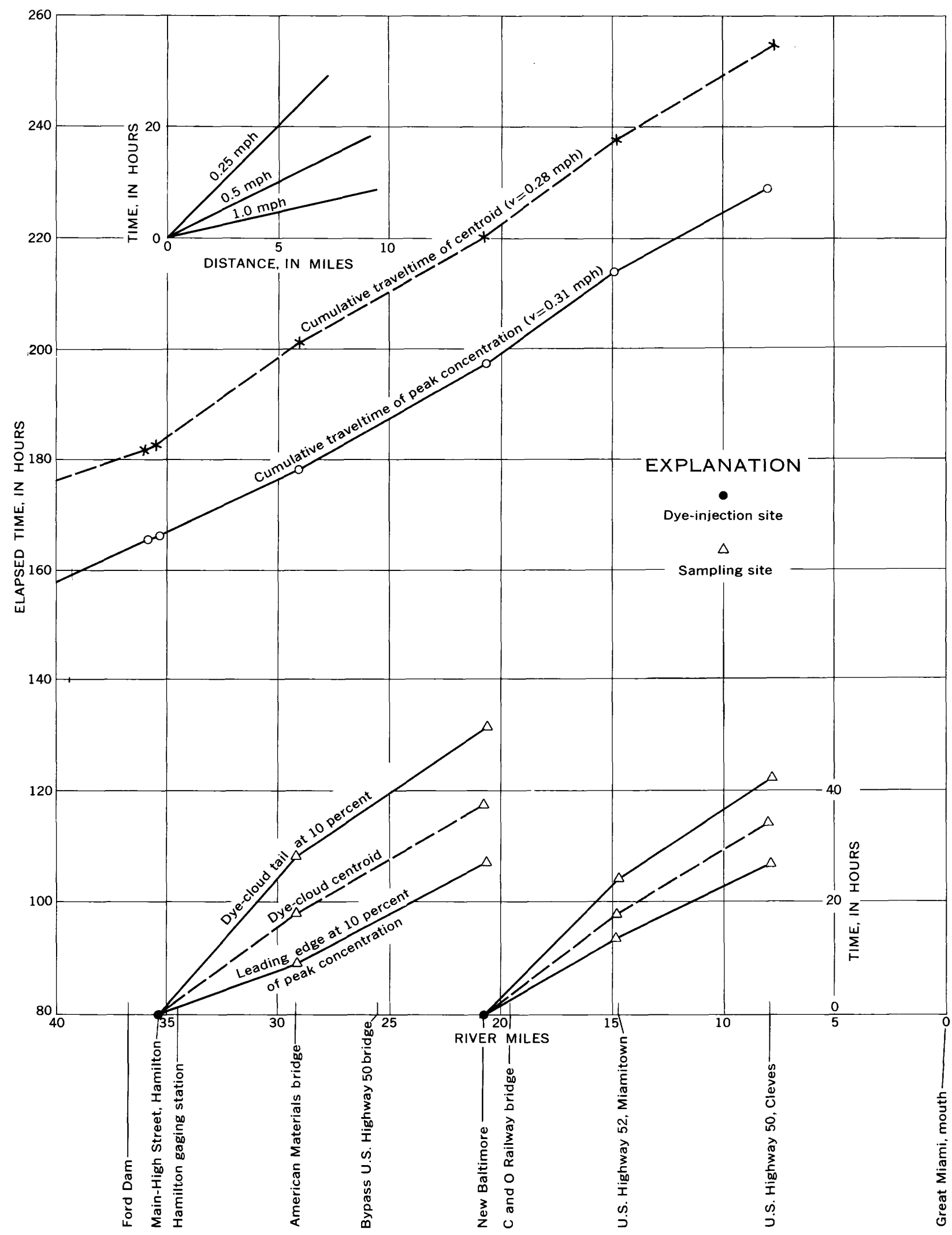

Figure 8. - Traveltime of dye cloud and longitudinal dispersion characteristics of Great Miami River at index flow of $380 \mathrm{cfs}$, mile 40 to mile 0 . 
Table 1.- Traveltime for index discharge of 550 cubic feet per second at Miamisburg, July 13-15, 1965

\begin{tabular}{|c|c|c|c|c|c|c|c|}
\hline Location & $\begin{array}{c}\text { Distance } \\
\text { from } \\
\text { mouth } \\
\text { (miles) }\end{array}$ & $\begin{array}{c}\text { Mean } \\
\text { discharge } \\
\text { (cfs) }\end{array}$ & $\begin{array}{l}\text { Traveltime of } \\
\text { centroid of } \\
\text { mass from } \\
\text { previous site } 2 \\
\text { (hr) }\end{array}$ & $\begin{array}{c}\text { Mean velocity of } \\
\text { centroid between } \\
\text { present and } \\
\text { previous sites } \\
\text { (mph) }\end{array}$ & $\begin{array}{c}\text { Time leading } \\
\text { edge precedes } \\
\text { centroid }^{3} \\
(\mathrm{hr})\end{array}$ & $\begin{array}{c}\text { Persist- } \\
\text { ence after } \\
\text { centroid } \\
(\mathrm{hr})\end{array}$ & $\begin{array}{l}\text { Traveltime } \\
\text { of peak } \\
\text { concen- } \\
\text { tration } \\
(\mathrm{hr})\end{array}$ \\
\hline 3d St., Dayton ...... & 79.32 & 340 & & & & & \\
\hline Stewart St., Dayton & 77.95 & 360 & 3.2 & 0.42 & 0.9 & 0.7 & 2.7 \\
\hline Broadway Bridge, Dayton ${ }^{4} \ldots$. & 76.36 & 370 & 8.8 & .18 & 4.4 & 6.1 & 7.0 \\
\hline Sellars Rd & 72.90 & 490 & 12.3 & .28 & 3.6 & 5.5 & 9.9 \\
\hline West Carrollton Dam & 71.48 & 490 & 10.0 & .14 & 6.2 & 8.0 & 11.2 \\
\hline West Carrollton $\mathrm{Rd}$ & 69.00 & 520 & 3.1 & .79 & 5.7 & 6.0 & 4.4 \\
\hline Sycamore St., Miamisburg ${ }^{4} \ldots$ & 66.44 & 540 & 6.0 & .43 & 5.8 & 5.2 & 4.6 \\
\hline Chautauqua Road Bridge........ & 63.84 & 540 & 11.6 & .22 & 4.5 & 9.6 & 9.0 \\
\hline Chautauqua Dam & 61.70 & 520 & 8.4 & .25 & 7.0 & 9.0 & 9.6 \\
\hline 2d St., Franklin, via canal & 59.71 & 510 & 7.8 & .25 &.-- & $--\ldots$ & 5.5 \\
\hline Chautauqua Dam. & 61.70 & 520 & --- & --- & 7.0 & 9.0 & $---n$ \\
\hline 2d St., Franklin, via river & 59.71 & 510 & 9.8 & .20 & -- & $-\ldots$ & 10.8 \\
\hline Near Oxford Rd ..... & 57.93 & 540 & 4.2 & .42 & 1.9 & 3.2 & 3.0 \\
\hline Middletown Dam & 55.82 & 570 & 8.9 & .24 & 3.9 & 6.2 & 9.0 \\
\hline Middletown Canal, at State Route 4.- & 54.24 & 240 & 4.6 & .34 & 4.1 & 6.4 & 3.2 \\
\hline $\begin{array}{l}\text { Midaletown Canal south, at state } \\
\text { Route } 122\end{array}$ & 52.74 & 240 & 3.3 & .46 & 4.6 & 7.0 & 4.0 \\
\hline Middletown Dam......... & 55.82 & 570 & $-\ldots$ & & 3.9 & 6.4 & ---- \\
\hline River-State Route 4 & 54.24 & 330 & 4.8 & .33 & 4.3 & 7.1 & 4.0 \\
\hline River-State Route 122 & 52.74 & 330 & 7.4 & .20 & 6.9 & 10.7 & 6.5 \\
\hline Middletown Dam. & 55.82 & 570 & $\ldots$ & $-\ldots$ & 3.9 & 6.4 & ---- \\
\hline $500 \mathrm{ft}$ upstream, State Route 73 bridge ${ }^{4}$ & 48.47 & 590 & 21.2 & .35 & 9.8 & 13.9 & 20.5 \\
\hline Woodsdale Bridge & 42.36 & 620 & 10.3 & .59 & 3.1 & 4.6 & 8.7 \\
\hline 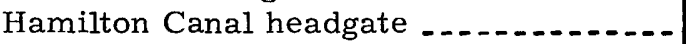 & 40.68 & 610 & 7.6 & .60 & 3.2 & 4.7 & 7.4 \\
\hline Canal outfall ..... & 36.00 & 610 & 6.0 & .78 & 3.5 & 6.1 & 5.5 \\
\hline Main-High St., Hamilton ${ }^{4}$ & 35.52 & 620 & 1.6 & .30 & 3.2 & 5.1 & 2.3 \\
\hline $1,000 \mathrm{ft}$ downstream Hamilton gage & 34.46 & 640 & .7 & 1.47 & .1 & .1 & .6 \\
\hline American Materials bridge & 29.30 & 680 & 10.0 & .52 & 4.6 & 7.2 & 7.8 \\
\hline U.S. Bypass $50 \ldots$ & 25.56 & 680 & 7.7 & .48 & 6.8 & 11.4 & 6.8 \\
\hline New Baltimore ${ }^{4}--$ & 20.84 & 710 & 8.2 & .57 & 7.0 & 15.1 & 7.4 \\
\hline Chesapeake and Ohio Railway bridge.... & 19.64 & 720 & 1.5 & .81 & .6 & .2 & 1.0 \\
\hline U.S. 52, Miamitown & 14.90 & 710 & 9.9 & .48 & 3.9 & 3.3 & 8.1 \\
\hline U.S. 50, Cleves_-- & 7.98 & 690 & 12.0 & .57 & 6.3 & 8.7 & 12.2 \\
\hline
\end{tabular}

\footnotetext{
${ }^{1}$ Total mileage $=71.3$ miles.

${ }^{3}$ Computed for 10 percent of peak concentration.

${ }^{2}$ Total centroid traveltime $=182 \mathrm{hr}$; average velocity $=0.39 \mathrm{mph} . \quad{ }^{4}$ Dye-injection points.
} 
Table 2.-Traveltime for index discharge of 380 cubic feet per second at Miamisburg, Aug. 31 to Sept. 2, 1965

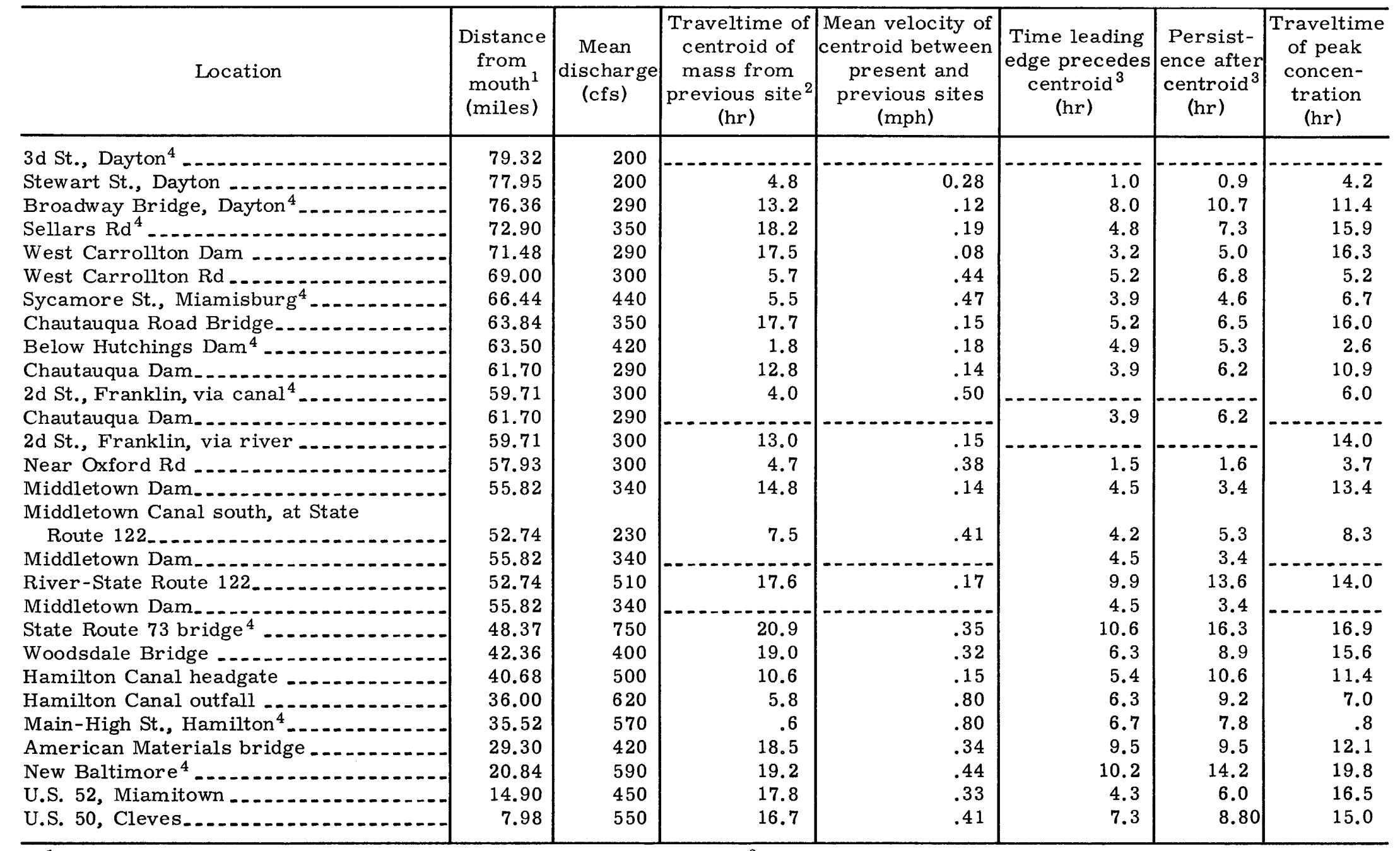

\footnotetext{
${ }^{1}$ Total mileage $=71.3$ miles.

${ }^{2}$ Total centroid traveltime $=253.6 \mathrm{hr}$; average velocity $=0.28 \mathrm{mph} . \quad{ }^{4}$ Dye-injection points.
} 
no dye loss for the 1,200-foot distance between the canal outfall and Franklin.

Adequate discharge measurements were made at Middletown to determine flow in the river and in the canal.

Table 3 gives representative discharges for selected sites along the Great Miami River and its tributaries. For most sites, tributary discharges were adjusted for discharge from the intervening drainage area between the gage site and the mouth.
A summary of industrial- end municipalwaste effluents is given in tables 4 and 5 . Industrial-and municipal-waste effluents were computed on the assumption thet the flow rate was constant over the entire 24-hour day. Besides the industries which utilize ground water, there are also industries whick use the river water for cooling. Industries utilizing the river water for this purpose are not listed, for most of the water is returned to the stream.

Table 3.-Discharges at selected sites on Great Miami River and tributaries

\begin{tabular}{|c|c|c|c|c|c|c|}
\hline \multirow{2}{*}{ Stream } & \multicolumn{6}{|c|}{ Mean discharge (cfs) } \\
\hline & $7-13-65$ & $7-14-65$ & $7-15-65$ & $8-31-65$ & $9-1-65$ & $9-2-65$ \\
\hline Great Miami at Dayton & 333 & 320 & 312 & 200 & 355 & 255 \\
\hline Wolf Creek & 6 & 6 & 6 & 6 & 50 (p eak) & 5 \\
\hline Bear Creek ${ }^{1}$ & 6 & 6 & 6 & 2 & 2 & 2 \\
\hline Great Miami at Miamisburg & 552 & 544 & 530 & 295 & 652 & 395 \\
\hline Great Miami at Franklin ${ }^{2} \ldots$ & 520 & 510 & 500 & 290 & 380 & 350 \\
\hline Clear Creek $^{2} \ldots$ & 2 & 2 & 2 & 1 & 4 & 3 \\
\hline Twin Creek ${ }^{1}$ & 24 & 22 & 21 & 8.1 & 13 & 12 \\
\hline Great Miami at Middletown, canal ... & 240 & 240 & 240 & 230 & 230 & 240 \\
\hline Great Miami at Middletown, river ${ }^{2}$ & 340 & 330 & 320 & 50 & 200 & 280 \\
\hline Elk Creek & 2 & 2 & 2 & 1 & 4 & 2 \\
\hline Dicks Creek & 4 & 4 & 4 & 8 & 18 & 7 \\
\hline Four Mile Creek & 20 & 18 & 15 & 5 & 10 & 7 \\
\hline Great Miami at Hamilton & 642 & 623 & 594 & 315 & 498 & 676 \\
\hline Indian Creek ${ }^{1}$ & 1 & 1 & 1 & .5 & 2 & 1 \\
\hline Great Miami at New Baltimore....... & 720 & 710 & 680 & 370 & 480 & 900 \\
\hline Great Miami at Cleves ${ }^{3}$ & - & -...... & 664 & $\ldots \ldots$ & $-\ldots$ & 551 \\
\hline
\end{tabular}

${ }^{1}$ Discharge adjusted for drainage-area change between gage site and mouth.

${ }^{2}$ Nonrecording gage; discharge computed from 8:00 a.m. reading each day.

${ }^{3}$ Measurements, July 15 at 10:00 a.m. and Sept. 2 at 9:00 a.m.

Table 4.-Municipal sewage-plant effluent

\begin{tabular}{|c|c|c|c|c|c|c|}
\hline \multirow{2}{*}{ City } & \multicolumn{6}{|c|}{ Mean discharge (cfs) } \\
\hline & $7-13-65$ & $7-14-65$ & $7-15-65$ & $8-31-65$ & $9-1-65$ & $9-2-65$ \\
\hline Dayton & 75.5 & 76.9 & 74.8 & 69.1 & 75.3 & 66.0 \\
\hline Hamilton & 11.3 & 11.4 & 11.6 & 11.6 & 15.1 & 12.8 \\
\hline Miamisburg & 2.2 & 2.2 & 2.2 & 2.0 & 2.3 & 2.1 \\
\hline Middletown & 9.7 & 9.7 & 9.7 & 18.3 & 10.7 & 12.7 \\
\hline Franklin & .1 & .1 & .1 & .1 & .1 & .1 \\
\hline West Carrollton $^{1}$ & 1.0 & 1.0 & 1.0 & 1.0 & 1.0 & 1.0 \\
\hline Miami Shores ${ }^{1}$ & 1.0 & 1.0 & 1.0 & 1.0 & 1.0 & 1.0 \\
\hline Totals_. & 100.8 & 102.3 & 100.4 & 103.1 & 105.5 & 95.7 \\
\hline
\end{tabular}

\footnotetext{
${ }^{1}$ Approximate effluent by graphical comparison.
} 
Table 5. -Waste effluent from industries using ground-water supply

\begin{tabular}{|c|c|c|c|c|c|c|}
\hline \multirow{2}{*}{ Plant } & \multicolumn{6}{|c|}{ Mean discharge (cfs) } \\
\hline & $7-13-65$ & $7-14-65$ & $7-15-65$ & $8-31-65$ & $9-1-65$ & $9-2-65$ \\
\hline $\begin{array}{l}\text { National Cash Register Co., Dayton } \\
\text { Howard Paper Div., St. Regis Paper } \\
\text { Co., Dayton }{ }^{1}\end{array}$ & 9.5 & 9.8 & 10.4 & 8.2 & 16.5 & 7.7 \\
\hline Frigidaire Corp., Dayton ${ }^{1}$ & ...... &.- &.- & $-\ldots-n$ &..-- & \\
\hline Frigidaire Corp., Moraine City .... & 30.1 & 30.3 & 30.3 & 28.9 & 19.1 & 18.7 \\
\hline Parchment Co., West Carrollton & 1.7 & 1.7 & 1.7 & 1.7 & 1.7 & 1.7 \\
\hline $\begin{array}{l}\text { Oxford Paper Co., North Carrollton. } \\
\text { Kimberly-Clark Corp., West }\end{array}$ & 5.6 & 5.6 & 5.6 & 6.2 & 6.2 & 6.2 \\
\hline Carrollton & 7.8 & 7.8 & 8.5 & 6.5 & 2.5 & 7.7 \\
\hline $\begin{array}{l}\text { Miamisburg Box Board Div., Inter- } \\
\text { state Folding Box Co., Miamisburg. }\end{array}$ & & & & 1.7 & 1.7 & 1.7 \\
\hline $\begin{array}{l}\text { Cheney Pulp and Paper Co., Franklin. } \\
\text { Miami Valley Coated Paper Div., }\end{array}$ & .4 & .4 & .4 & .4 & .4 & .4 \\
\hline Millen Industries, Franklin & .1 & .1 & .1 & .1 & .1 & .1 \\
\hline Logan Long Co., Franklin & .3 & .3 & .3 & .3 & .3 & .3 \\
\hline $\begin{array}{l}\text { Stone Container Corp., Franklin... } \\
\text { Harding Jones Paper Co., }\end{array}$ & .8 & .8 & .8 & .8 & .8 & .8 \\
\hline Middletown & 1.3 & 1.3 & 1.3 & 1.3 & 1.4 & 1.4 \\
\hline $\begin{array}{l}\text { Sorg Paper Co., Middletown } \\
\text { Wren Paper Div., Mead Paper Corp., }\end{array}$ & 3.8 & 4.1 & 3.9 & 2.4 & 2.5 & 3.0 \\
\hline Middletown & .9 & .9 & .9 & .9 & .9 & .9 \\
\hline Crystal Tissue Co., Middletown & 3.6 & 3.6 & 3.6 & 3.5 & 3.5 & 3.5 \\
\hline $\begin{array}{l}\text { Armco Steel Corp., Middletown } \\
\text { U.S. Plywood, Champion Paper, Inc., }\end{array}$ & 15.5 & 15.5 & 15.5 & 15.5 & 15.5 & 15.5 \\
\hline Hamilton & & & 20.6 & 19.8 & 19.3 & 18.4 \\
\hline Nicolet Industries, Inc., Hamilton & 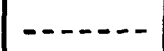 &.- & $\ldots$ & .2 & .2 & .2 \\
\hline Totals ..- & 81.4 & 82.2 & 103.9 & 98.4 & 92.6 & 88.2 \\
\hline
\end{tabular}

${ }^{\mathbf{1}_{\text {Tied }}}$ in with city sewer.

\section{DE TE RMINATION OF MIAMISBURG INDEX DISCHARGE}

During the July run, discharges at Miamisburg remained nearly constant during the run. Over this time span, an average index discharge of $550 \mathrm{cfs}$ was computed for Miamisburg. The index discharge is defined as the average discharge at Miamisburg for the traveltime occurrence.

During the August run, a rainstorm occurred covering the entire reach under consideration with approximately $1-1 \frac{1}{4}$ inches of rainfall. Generally, peak dye-cloud concentration occurred at all sampling sites before the effects of the rainfall were noted. Many of the tailing ends of the time-concentration curves were affected and caused a dilution effect in some places. In a few of the more critical situations, the concentration curves were extended by estimating the recessions. To determine the effects of the rain more thoroughly, a dis charge-drainage-area relation was computed for each concentration curve, based on the time of occurrence of the centroid. Results of computations showed discharge per square mile to range from 0.078 to $0.241 \mathrm{cfs}$ with an average of $0.128 \mathrm{cfs}$. Eighty-seven percent of the values ranged from 0.100 to $0.179 \mathrm{cfs}$ witk only one extreme of $0.241 \mathrm{cfs}$. It was therefore concluded that the rainfall had minor effect.

The computation of index discharge for the August run was determined by considering sampling-site discharge, drainage area, and mean discharge at Miamisburg. (See takle 6.) To arrive at a representative value, the follow ing procedure was used: A discharge factor was computed for each sampling site, the discharge factor being defined as the quotient of the mean Miamisburg discharge and the mean sampling-site discharge. Discharge results from the July run were used to compute the discharge factors. Mean sampling-site discharges were then computed for the fugust run. Next, Miamisburg index discharges for 
Table 6. - Miamisburg index discharges for mean discharges in subreaches during August run

\begin{tabular}{|c|c|c|c|c|}
\hline Location & $\begin{array}{c}\text { Mean } \\
\underset{(\text { discharge }}{\operatorname{defs})^{1}}\end{array}$ & $\begin{array}{c}\text { Discharge } \\
\text { factor } \\
(\boldsymbol{F})\end{array}$ & $\begin{array}{l}\text { Product } \\
\text { QxF } \\
\text { (cfs) }\end{array}$ & $\begin{array}{l}\text { Average } \\
\text { Miamisburg } \\
\text { index } \\
\text { discharge } \\
\text { (cfs) }\end{array}$ \\
\hline 3d St., Dayton' & 203 & 1.59 & 323 & 312 \\
\hline Stewart St., Dayton & 200 & 1.50 & 300 & 368 \\
\hline Broadway Bridge, Dayton & 291 & 1.46 & 437 & \\
\hline Broadway Bridge, Dayton ${ }^{2}$ & 202 & 1.46 & 295 & 318 \\
\hline Sellars Road & 310 & 1.10 & 341 & \\
\hline Sellars Road ${ }^{2} \ldots \ldots$ & 291 & 1.10 & 320 & 318 \\
\hline West Carrollton Dam ... & 288 & 1.10 & 317 & 320 \\
\hline West Carrollton Road & 310 & 1.04 & 322 & 355 \\
\hline Sycamore St., Miamisburg & 388 & 1.00 & 388 & \\
\hline Sycamore St., Miamisburg ${ }^{2}$ & 290 & 1.00 & 290 & 325 \\
\hline Chautauqua Road Bridge & 360 & 1.00 & 360 & 389 \\
\hline Below Hutchings Dam & 410 & 1.02 & 418 & \\
\hline Below Hutchings Dam² & 293 & 1.02 & 299 & 302 \\
\hline Chautauqua Dam & 294 & 1.04 & 306 & 310 \\
\hline 2d St., Franklin & 295 & 1.06 & 313 & \\
\hline 2d St., Franklin2 & 295 & 1.06 & 313 & 304 \\
\hline Near Oxford Road & 295 & 1.00 & 295 & 309 \\
\hline Middletown Dam & 340 & .95 & 323 & 484 \\
\hline State Route 73 Bridge & 700 & .92 & 644 & \\
\hline State Route 73 Bridge $^{2}$ & 316 & .92 & 291 & 321 \\
\hline Woodsdale Bridge & 404 & .87 & 351 & 404 \\
\hline Hamilton Canal headgate & 514 & .89 & 457 & 496 \\
\hline Hamilton Canal outfall & 600 & .89 & 534 & 524 \\
\hline Main-High St., Hamilton & 590 & .87 & 513 & \\
\hline Main-High St., Hamilton ${ }^{2}$ & 315 & .87 & 274 & 307 \\
\hline American Materials bridge & 425 & .80 & 340 & 394 \\
\hline New Baltimore & 590 & .76 & 448 & \\
\hline New Baltimore ${ }^{2}$ & 370 & .76 & 281 & 300 \\
\hline U.S. 52, Miamitown & 420 & .76 & 319 & 366 \\
\hline U.S. 50, Cleves. & 530 & .78 & 413 & \\
\hline
\end{tabular}

1Mean discharge at the time of dye-cloud passage or at the time of dye injection.

2Dye-injection locations.

each sampling site were determined from the product of the mean sampling-site discharges and the respective discharge factors. Index discharges at the upstream and downstream ends of each subreach were then averaged. Instead of using an arithmetic average of the tabulated discharge, it was felt that weighting each discharge by its incremental reach drainage area would give a truer discharge index for the entire reach, Dayton to Cleves. By this method, an index discharge for the Miamishurg gage was computed to be $380 \mathrm{cfs}$. This index is limited to applications involving the entire stream reach, and if indices are desired for other subreaches, from Dayton to Middletown, for example, a similar computation would have to be followed.

\section{TRAVELTIME PREDICTICN}

To predict traveltimes, a linear $\log -\log$ plot of traveltime versus Miamisburg index discharge was made. A straight line was drawn between the two points and an equation developed for the curve. The equation which was developed for the entire reach, Dayton to Cleves, is, $T=400 \times 10^{2} Q-.85$, where $T$ is traveltime in hours and $Q$ is discharge in cfs.

The above equation is applicakle for an approximate index-discharge span of $300-800$ cfs; these limits were determined from a study of varying Miamisburg index discharges and the corresponding stream cross-sentional areas at random sites along the reach. 
The two index discharges of 550 and $380 \mathrm{cfs}$ represent flow durations of 76 and 90 percent, respectively, at Miamisburg. The index discharges therefore represent very low flow conditions, and the traveltimes are nearly the longest and the longitudinal spreads a re nearly the greatest to be expected. An accidental spill at a discharge much greater than $550 \mathrm{cfs}$ would travel faster and be less dispersed.

\section{DYE-CLOUd PASSAGE TIME}

Passage time of the dye cloud may be determined by inspection of the curves in figures 5-8. The time intervals from the centroids of the concentration curves are plotted and are given in tables 1 and 2. Because of the uncertainty of the actual beginning or ending of many concentration curves, values were taken at 10 percent of the peak concentration. By using 10 percent of the peak concentration instead of zero concentration, the differences for the leading edges are usually slight; for most cases, the trailing edge 10-percent point is significantly short of the point of nondetectability.

As a point of interest, the Middletown canal and river longitudinal dispersion characteristics are also shown on figure 5. Only an average centroid curve is plotted; both the canal and river values were plotted from this base.

By comparing the longitudinal dispersion characteristics of the two runs, some uncommon time-concentration patterns are noted that are similar to those reported by Godfrey and Frederick (1963). This variation can be attributed to the many controls and extensive use of the stream. Even if a rerun would be possible at discharges equal to those during this study, the resulting shape of the timeconcentration curve would probably differ.

\section{CONCLUSIONS}

The time-of-travel study of the Great Miami River gave representative traveltimes for the river during low streamflow between Dayton and Cleves, a distance of 71.3 river miles. The longitudinal spread of the dye cloud showed unusual effects, especially in the upper portion of the reach where the stream is highly controlled. Comparison of observed traveltimes with those computed by using the averagevelocity method indicated very poor correlation between the two methods. The averagevelocity method indicated a faster traveltime for a given index discharge at Miamisburg. Within the index-discharge range, 300-800 cfs, one may make reasonable estimates of time of travel for a given index discharge. However, extrapolations of the traveltime-discharge relation beyond that range should be made with caution.

\section{SELECTED REFERENCES}

Buchanan, T. J., 1964, Time of travel of soluble contaminants in streams: Am. Soc. Civil Engineers Proc., v. 90, no. SA3, paper 3?32, 12 p., 6 fig.

Godfrey, R. G., and Frederick, B. J., 1963, Dispersion in natural streams: U.S. Geol. Survey open-file report, 75 p., 13 fig.

Stewart, M. R., 1967, Time of travel of solutes in Mississippi River, Baton Rouge to $\mathrm{I}^{\top} \mathrm{ew}$ Orleans, Louisiana: U.S. Geol. Survey Hydrol. Inv. Atlas HA-260.

Wilson, J. F., Jr., and Forrest, W.' E., 1§65, Potomac River time-of-travel measurements, in Symposium on diffusion in oceans and fresh waters: Palisades, N. Y., Lamont Geol. Observatory, 1964, 18 p., 6 fig.

* U. S. GOVERNMENT PRINTING OFFICE : 1968 O - 285-061 
